\title{
DIRECTIONS FOR IMPROVEMENT \\ OF ADMINISTRATIVE AND LEGAL REGULATION \\ OF DOMESTIC TRADE
}

\section{НАПРЯМКИ УДОСКОНАЛЕННЯ \\ АДМІНІСТРАТИВНО-ПРАВОВОГО РЕГУЛЮВАННЯ СФЕРИ ВНУТРІШНЬОЇ ТОРГІВЛІ}

\section{Inna Kravchenko ${ }^{1}$ \\ Olga Kolodochka²}

DOI: https://doi.org/10.30525/978-9934-588-15-0-84

Abstract. The purpose: determination of directions and ways to improve domestic trade in Ukraine. Internal trade is an integral component of the existence of an economic society and a kind of indicator the standard of living society. The strategic goal of state regulation domestic trade is the formation and stabilization of the consumer market to meet social needs and prevent social tension in society. Methodology. The theoretical and methodological foundations of the study key areas and strategies for the development of domestic trade in Ukraine. For research, such methods were used as: comparison - to compare the procedure for administering domestic trade in Ukraine and foreign countries; formalization method - manifests itself in the formation of specific proposals for improving the internal trade system in Ukraine; analysis - in identifying common patterns and areas of regulation of the sphere of domestic trade in Ukraine. Results The government should be the initiator of the reform in the field of trade activities, the guarantor of legal support for the equal rights of all subjects of ownership, legality and protection of consumer rights. State regulation of a rule-of-law state with a developed market economy should be limited to a monitoring policy on anti-monopoly principles of relations between market entities, promotion of competition, respect for the rights and interests of consumers,

${ }^{1}$ Candidate of Juridical Science,

Lecturer at the Constitutional and Administrative Law and Proceedings Department, Petro Mohyla Black Sea State University, Ukraine

${ }^{2}$ Lecturer at the Constitutional and Administrative Law and Proceedings Department, Petro Mohyla Black Sea State University, Ukraine 
and other legal rules for regulating business in the field of trade; the impact on the staffing of trading activities in market conditions. Ways to develop the administrative and legal foundations of retail trade are to create a competitive environment; ensuring reliability and economic competitiveness; preventing the liquidation of socially important trading enterprises; the maximum adaptation of retail to the needs of consumers; a combination of principles of free and regulated formation of a retail network; development of a standardization and certification system; reducing the list of trading activities subject to licensing; improving the mechanism for counteracting the sale of low-quality products.

\section{1. Ветуп}

Внутрішня торгівля є невід'ємною складовою існування економічного суспільства і своєрідним індикатором життєвого рівня населення та соціальної політики держави. Через мережу об'єктів внутрішньої торгівлі фізичні та юридичні особи задовольняють переважну кількість своїх матеріальних, а в багатьох випадках - і нематеріальних потреб. Саме внутрішня торгівля $є$ тим засобом, через який громадяни щодня забезпечують своє невід'ємне право на гідний рівень життя і здоров'я шляхом купівлі в торговельних закладах споживчих товарів. Завдяки внутрішній торгівлі стає можливим дотримання балансу між виробництвом і споживанням, формується суттєва частка валової доданої вартості в Україні, забезпечується робочими місцями економічно активне населення. Беззаперечно, що по тому, як працює торгівля, найчастіше судять про роботу апарату держави, про успіх соціальних і економічних реформ.

Так, Конституція України визначила, що держава захищає права споживачів, здійснює контроль за якістю і безпечністю продукції та усіх видів послуг і робіт, сприяє діяльності громадських організацій споживачів. Результати проведеного соціологічного опитування свідчать, що 62\% громадян та 92\% суб'єктів торговельної діяльності визнають стан державного регулювання внутрішньої торгівлі як незадовільний. Незадоволення суспільства розвитком внутрішнього ринку $\epsilon$ очевидним, адже відсутність сьогодні цивілізованих правил торгівлі позначається на інтересах покупців, виробників і навіть продавців.

Таким чином, питання адміністративно-правового регулювання внутрішньої торговельної діяльності в Україні були і залишаються акту- 
альними, що зумовлюється як відсутністю досконалих правил торгівлі в державі, так і нагальною потребою щодо реалізації нових підходів у вдосконаленні законодавства та управлінської діяльності у цій галузі, а також необхідністю практичного застосування в Україні світових та європейських стандартів державного регулювання торгівлі.

Наведене обумовлюс необхідність здійснення теоретичного узагальнення та подальшого вирішення наукового завдання стосовно адміністративно-правового регулювання внутрішньої торгівлі в Україні.

\section{2. Розвиток адміністративно-правових засад у сфері внутрішньої торгівлі}

Внутрішня торгівля $є$ однією 3 важливих галузей економіки, яка відіграє значну роль як у формуванні економічного потенціалу України, так і в задоволенні потреби споживачів у високоякісних товарах i послугах.

Основи розвитку адміністративно-правових засад торговельної діяльності містяться в положеннях торгової політики, оскільки торгова політика передбачає прискорений розвиток виробництва товарів народного споживання як матеріального підгрунтя ефективного функціонування внутрішньої торгівлі; подолання структурних деформацій розвитку галузі шляхом створення адекватної умовам і вимогам економічного зростання ринкової інфраструктури. Як складова макроекономічної політики держави, торгова політика спирається на всю сукупність методів, засобів, інструментів системи державного регулювання економіки [4, с. 9-10].

Практичною умовою створення і реалізації торгової політики держави за умов ринкової трансформації має стати розв'язання таких головних завдань: оцінка умов і факторів конкуренції в національних секторах ринку та галузях глобальної конкуренції; проведення структурної перебудови економіки з метою прискореного розвитку конкурентоспроможних галузей та підприємств; підвищення ефективності використання національних ресурсів, передусім зменшення енерго- i матеріаломісткості продукції як необхідної умови конкурентоспроможності; прискорення інституціональної трансформації економіки; узгодження зусиль держави і суб'єктів господарювання у розвитку конкурентоспроможних галузей економіки; розвиток ринкової інфра- 
структури, вдосконалення та стабілізація нормативно-правового поля конкуренції та його інтеграція у світове конкурентне середовище.

Основними перешкодами на шляху реалізації запропонованих заходів є: надмірні ціни кредитних ресурсів, які зводять нанівець зусилля підприємств 3 модернізації, технічного переоснащення та структурної перебудови виробництва; соціальні проблеми ринкової трансформації.

Крім суто матеріальних умов реалізації торгової політики, іiї втілення значною мірою залежить від стану інституціональної трансформації економіки у напрямку створення ринкового середовища 3 конкурентною атмосферою. Головними невирішеними проблемами в цій сфері залиша-ються: обмежена кількість ефективних суб'єктів господарювання; недостатній розвиток ринкової інфраструктури; нестабільне і невиважене правове поле конкуренції.

Необхідною умовою функціонування ринкових відносин взагалі i розвитку доброякісної конкуренції зокрема є наявність в державі ринкової інфраструктури. В Україні цей атрибут ринку поки що не знайшов належного втілення. Недостатньо розвинені фінансово-кредитний, страховий та фондовий ринки. Дається взнаки нерозвиненість товарних бірж, торгових домів, торгово-промислових палат, бізнес-центрів, регіональних фондів підтримки підприємництва та обмеженість інформаційних можливостей підприємців у вивченні кон'юнктури ринку - як внутрішнього, так і зовнішнього. Ці фактори обумовлюють необхідність запровадження матеріальних стимулів для розвитку інфраструктурного сектору, а саме зменшення чи звільнення від оподаткування: прибутків банків, отриманих від надання довгострокових кредитів (на 5 і більше років); операцій з цінними паперами за умови функціонування Національного депозитарію; доходів від зростання депозитних вкладів банків, контрольний пакет яких належить резидентам.

Через недостатнє економічне обгрунтування законів і нормативних актів 3 питань оподаткування, тарифного та валютного регулювання, а також системи пільг порушується стабільність правового поля. Численні зміни «правил гри» на ринку товарів і послуг ускладнюють умови підприємництва не тільки національним виробникам, але й іноземним учасникам економічних відносин. Подолання такого становища потребує: усунення бар'єрів, які перешкоджають вступу України до Європей- 
ського Союзу, укладенню з ним угоди про вільну торгівлю; припинення будь-якого втручання у правове поле конкуренції без детального обгрунтування економічної доцільності з точки зору позитивного впливу на конкурентоспроможність економіки; наближення вітчизняних умов господарювання до світової практики; звільнення собівартості від невластивих для неї відрахувань до цільових фондів (крім Пенсійного), обов'язкових зборів і платежів, надання підприємствам можливості повністю розпоряджатися амортизаційними відрахуваннями [4, с. 9-13].

Вважаємо, що розвиток адміністративно-правових засад внутрішньої торгівлі базується на таких основоположних засадах:

1) основоположні засади розвитку адміністративно-правового регулю-вання внутрішньої торгівлі містяться у положеннях внутрішньої торговельної політики України як складової макроекономічної політики держави, що спирається на сукупність методів, засобів, інструментів системи державного регулювання;

2) на думку вчених-економістів, ефективними напрямками політики держави у сфері внутрішньої торгівлі є: сприяння інвестиційному клімату; пріоритетний розвиток галузей легкої та харчової промисловості; створення повноцінного ринкового конкурентного середовища; формування прошарку ефективних власників; соціальна відповідальність власників; розвиток внутрішнього споживчого ринку; державна підтримка торгівлі соціальними продуктовими товарами; формування стабільного законодавства та системи державного управління внутрішньою торгівлею;

3) до основних напрямків підвищення ефективності внутрішньої тор-гівлі вчені відносять: зростання платоспроможності населення; зростання виробництва споживчих товарів; вдале використанням концентрації та спе-ціалізації торгівлі, вдосконалення регіональної організації торгівлі; вдоско-налення організаційно-правових форм підприємництва; розвиток оптових продовольчих ринків та електронних торговельних порталів; забезпечення якості і безпеки товарів; розвиток мережі збуту продукції безпосередньо виробниками (фірмова торгівля); зниження податкового тиску; попередження недобросовісної конкуренції; стимулювання ресурсозбереження.

Державне регулювання розвитку внутрішньої торгівлі здійснюється через нормативно-правову та методичну базу; контрольно-наг- 
лядову і обмежувально-заборону систему заходів; вибіркову державну підтримку важливих соціально-економічних орієнтирів. Безпосередньо в адміністративно-правовому аспекті слушними залишаються деякі положення щодо розвитку торговельної діяльності в адміністративно-правовому аспекті, висвітлені в Концепції розвитку внутрішньої торгівлі України, затвердженій Постановою Кабінету Міністрів України від 20 грудня 1997 р. № 1449.

Основою правового регулювання торговельної діяльності на допов-нення до чинного законодавства повинен бути Закон України «Про внутрішню торгівлю», який започаткує створення законодавчої бази для забезпечення умов, які сприяли б ефективній підприємницькій діяльності на принципах вільного підприємництва. Це вдосконалить правовий статус організаційних форм торговельної діяльності, дасть змогу регламентувати права і відповідальність тї суб' єктів, більш обгрунтовано визначати заходи державного регулювання і підтримки підприємництва в торгівлі.

У Постанові зазначається, що відповідно до розвитку Закону України «Про внутрішню торгівлю» необхідно розробити або удосконалити нормативно-правову та методичну базу з питань ліцензування i патентування торговельної діяльності; контролю за якістю товарів і послуг; створення сприятливого інвестиційного клімату в сфері торгівлі з орієнтацією капітальних вкладень, особливо іноземного капіталу, в розвиток матеріально-технічної бази торгівлі та розбудови іiі інфраструктури; правового регулювання торговельних угод; структуризації мережі підприємств торгівлі та громадського харчування; підвищення науково-технічного рівня через галузеві стандарти і нормативи торговельної діяльності; професійно-кадрової відповідності (вимоги до професійної підготовки); інформаційного забезпечення торговельної діяльності; стандартизації понять, термінів і визначень у сфері торгівлі та організації харчування.

На думку авторів Постанови, необхідно, щоб державна підтримка торговельної діяльності здійснювалася шляхом надання позик на придбання, створення або розширення підприємств у певних місцевостях; фінансування участі у капіталі великих підприємств; довгострокових інвестиційних проектів, пов'язаних, наприклад, зі створенням або збереженням робочих місць; технічного оснащення підприємств; надання 
гарантій кредитним товариствам, банкам, фінансовим компаніям; сприяння розвитку послуг у сфері транспортування, перевалки, оброблення та переробки вантажів з метою істотного підвищення рівня транспортно-експедиційного обслугову-вання вантажів у сфері торгівлі; сприяння розширенню торговельної присутності підприємств і організацій України на території інших країн; стимулювання заходів щодо охорони довкілля; підвищення кваліфікації кадрів; субсидіювання досліджень, що виконуються за державним замовленням, інвестицій у науково-дослідні роботи; консультаційної допомоги.

Реформування структурної та територіальної організації роздрібної торгівлі забезпечується її розвитком за відповідними функціональними напрямками.

Напрямок перший - формування ефективного конкурентного середо-вища для ринкових суб'єктів господарювання.

Напрямок другий - забезпечення господарської надійності та економічної конкурентоспроможності кожного ринкового суб'єкта.

Напрямок третій - запобігання скороченню або ліквідації деяких соціально важливих, але малоприбуткових і неконкурентоспроможних видів торговельної діяльності.

У системі державних заходів щодо забезпечення захисту прав $\mathrm{i}$ інтересів споживачів у сфері роздрібної торгівлі першочергової підтримки потребують такі: освоєння економічно малоефективних торговельних зон; торгівля екологічно чистими та такими, що швидко псуються, видами продукції; залучення на внутрішній ринок товарів, на які є стабільний попит; організація харчування в закладах освіти, дитячих, лікувальних, оздоровчих закладах тощо; організація харчування і торговельного обслуговування малозабезпечених, соціально незахищених та інших пільгових верств населення; розроблення та впровадження нових видів технологічного обладнання; забезпечення потреб цивільної оборони і стабільної роботи підприємств торгівлі в умовах надзвичайних ситуацій. Свою підтримку регіональні органи виконавчої влади повинні реалізовувати через систему замовлень або надання пільг суб'єктам торговельної діяльності.

Напрямок четвертий - максимальна адаптація структурної та територіальної організації роздрібної торговельної мережі до стереотипів і моделей поведінки споживачів та їх запитів. 
Напрямок п'ятий - поєднання принципів вільного (ринкового) та регульованого формування роздрібної торговельної мережі. Враховуючи, що роздрібна торговельна мережа $є$ елементом інфраструктури кожного міського і сільського поселення і виконує, крім економічної, значну соціальну функцію, необхідно відновити на принципово новій основі систему розроблення та затвердження перспективних планів розвитку і розміщення роздрібної торговельної мережі як складової генеральних планів-схем розвитку міст, міських районів і сільських адміністративних територій. Основними принципами визначення кількісних і якісних показників розвитку роздрібної торговельної мережі повинні стати суто «ринкові» принципи «економічної доцільності» $\mathrm{i}$ «переваг для споживачів».

Напрямок шостий - створення чіткої системи захисних і обмежувальних механізмів державного регулювання розвитку сфери роздрібної торгівлі. Широке застосування системи національних стандартів, нормативів, нормалей, технічних умов і правил у сфері торговельної діяльності повинно значно збільшити надійність комерційних відносин між товаровиробниками, продавцями і споживачами на всіх етапах переміщення товарів, підвищити ефективність правового захисту цих відносин з боку держави, зробити більш сприятливим інвестиційний клімат у цій сфері.

Напрямок сьомий - упорядкування організації та ведення торговельної діяльності. Поліпшенню торговельного обслуговування населення, а також запобіганню всілякого роду порушенням суб'єктами торговельної діяльності сприятиме більш цілеспрямована контрольованість і регламентація торговельної діяльності, що передбачає подальше удосконалення системи ліцензування і патентування різних видів торговельної діяльності 3 метою спрощення процедури одержання дозвільних документів, а також об'єктивізації цього процесу; проведення технічної паспортизації об'єктів торговельної мережі; додержання всіма суб'єктами господарювання єдиних правил продажу окремих груп споживчих товарів і ведення підприємницької діяльності у сфері торгівлі; упорядкування «вуличної» торгівлі відповідно до правил і технологічних вимог щодо продажу товарів через дрібнороздрібну, пересувну та виносну мережі; розвиток інфраструктури роздрібної торгівлі, зокрема пунктів гарантійного обслуговування 
складних технічних товарів, пунктів прокату виробів як альтернативи продажу дорогих товарів, мережі торговельних об'єктів 3 новими грошово-розрахунковими технологіями тощо; зміцнення матеріально-технічної бази місцевих ринків з продажу продовольчих і непродовольчих товарів та удосконалення порядку організації торгівлі на них; подальше удосконалення механізмів протидії надходженню у продаж неякісної та небезпечної продукції.

Довгостроковими цільовими орієнтирами розвитку сфери оптової торгівлі повинні стати створення розвинутої структури каналів переміщення товарів; підтримка необхідної інтенсивності товаропотоків; формування резервних джерел фінансового забезпечення процесу руху товарів.

Таким чином, розвиток адміністративно-правових засад торговельної діяльності характеризується такими рисами:

1) на етапі реформування економіки державне регулювання внутрішньої торговельної базується на принципах: організаційно-господарській незалежності суб'єктів торговельної діяльності, свободи вибору ними форм і видів торговельної діяльності; самоокупності (відповідне регулювання торговельної сфери через систему правових, науково-технічних, інвестиційних, соціально-політичних та інших механізмів);

2) стратегічною метою державного регулювання внутрішньої торгівлі $\epsilon$ формування та стабілізація споживчого ринку для задоволення соціальних потреб і недопущення соціальної напруженості у суспільстві;

3) співвідношення методів і механізмів державного регулювання розвитку внутрішньої торгівлі має змінюватись у бік розширення та посилення результативності економічних методів впливу на їх розвиток на противагу заборонно-дозвільним або обмежувальним механізмам регулювання;

4) держава має бути ініціатором реформування у сфері торговельної діяльності, гарантом правового забезпечення рівних прав усіх суб'єктів права власності, законності та охорони прав споживачів;

5) державне регулювання у післяприватизаційний період має обмежуватись моніторинговою політикою щодо антимонопольних принципів відносин суб'єктів ринку, сприяння розвитку конкуренції, дотримання прав і інтересів споживачів інших правових норм регламентації підприємництва у сфері торгівлі; впливом на кадрове забезпечення торговельної діяльності у ринкових умовах; 
6) напрямками розвитку адміністративно-правових засад роздрібної торгівлі є: формування конкурентного середовища; забезпечення надійності та економічної конкурентоспроможності; недопущення ліквідації соціально важливих торговельних підприємств; максимальна адаптація роздрібної торгівлі до потреб споживачів; поєднання принципів вільного і регульованого формування роздрібної торговельної мережі; розвиток системи стандартизації та сертифікації; зменшення переліку торговельної діяльності, яка підпадає під ліцензування; удосконалення механізму протидії надходженню у продаж неякісної продукції.

7) напрямками удосконалення адміністративно-правових засад оптової торгівлі є: створення умов для розвитку територіально розгалуженої мережі оптових підприємств; демонополізація каналів переміщення товарів; удосконалення стандартів у сфері оптової торгівлі.

Отже, критичний аналіз економічної та юридичної складової проблем у сфері розвитку внутрішньої торгівлі в Україні дає можливість обгрунтовано стверджувати, що науковий адміністративно-правовий супровід реформ у зазначеній сфері є добре розробленим. Залишається вдало його втілити у проекті Закону України «Про внутрішню торгівлю», а в майбутньому - і в кодифікованому нормативно-правовому акті - Торговому кодексі України.

\section{3. Шляхи вдосконалення законодавства у сфері внутрішньої торгівлі}

Відповідно до Розпорядження Кабінету Міністрів України від 7 жовтня 2009 р. № 1200-р було схвалено Концепцію проекту Закону України «Про внутрішню торгівлю». Вона визначила шляхи законодавчого врегулювання відносин, які виникають у процесі провадження торговельної діяльності, що має сприяти підвищенню ефективності державного регулювання та удосконаленню системи контролю у сфері внутрішньої торгівлі та захисту прав споживачів.

У Концепції зокрема зазначається, що істотними недоліками законодавства у сфері внутрішньої торгівлі $є$ невизначеність основ формування відповідної державної політики та відсутність єдиного підходу до вирішення питань, пов'язаних з діяльністю суб'єктів господарювання у зазначеній сфері; провадження торговельної діяльності ускладнюється відсутністю чіткого розподілу повноважень у сфері внутрішньої 
торгівлі між центральними та місцевими органами виконавчої влади, органами місцевого самоврядування, громадськими організаціями, об'єднаннями роботодавців і професійних спілок.

Визначаються новітні шляхи та способи розв'язання проблеми. Наприклад: формування конкурентного середовища у сфері внутрішньої торгівлі, досягнення належного рівня торговельного обслуговування та задоволення потреби споживачів у високоякісних товарах і послугах можливе лише за умови правового врегулювання відносин, які виникають під час провадження торговельної діяльності.

Слушними відповідно до розвитку зазначеного є погляди В.В. Хасанової, яка вважає, що з метою впорядкування законодавчого забезпечення державного регулювання внутрішньої торгівлі необхідним насамперед видається посилення ролі закону, а також юридичне закріплення сучасних засад державного регулювання у галузі внутрішньої торгівлі. Цьому сприятиме прийняття Закону України «Про внутрішню торгівлю», в якому повинні бути врегульовані такі питання: закріплення термінів, що використовуються у здійсненні торговельної діяльності; уніфікація дозвільних документів, необхідних для здійснення торговельної діяльності; встановлення державної реєстрації торговельних об'єктів і закладів ресторанного господарства; визначення основних засад державного регулювання у галузі внутрішньої торгівлі. Крім того, з метою удосконалення інституту ліцензування автор запропонувала запровадити диференціацію вартості ліцензії на право торгівлі алкогольними напоями та тютюновими виробами для магазинів - залежно від місця розташування і торгової площі або від місця розташування та товарообігу магазину; для закладів ресторанного господарства - залежно від торгової площі або від кількості посадочних місць [3, с. 15].

Загалом, на наш погляд, існує потреба:

- по-перше, більш детально прописати права і обов'язки суб'єктів торговельної діяльності;

- по-друге, не створювати на місцях територіальні підрозділи спеціаль-но уповноваженого органу виконавчої влади у сфері внутрішньої торгівлі, а його функції покласти на органи місцевого самоврядування та Державну податкову адміністрацію, позбавивши їх карних функцій;

- по-третє, чітко прописати обов'язки і права спеціально уповноваженого органу виконавчої влади у сфері внутрішньої торгівлі та деле- 
говані повноваження органів місцевого самоврядування у цій сфері;

- по-четверте, записати у перехідних положеннях, що ст. 24 діє до прийняття нового Кодексу про адміністративні проступки, а ст. 20 до вступу в дію Адміністративно-процедурного кодексу України.

Для ефективного покращення адміністративно-правового регулювання внутрішньої торгівлі в Україні слід враховувати позитивний і досвід зарубіжних держав в аналізованій сфері та використовувати його найкращі напрацювання 3 метою трансформування за національною специфікою.

Аналіз міжнародного досвіду пропонуємо провести на прикладі Німеччини - країни Євросоюзу з класичною Романо-Германською правової системою, в якій існує окрема галузь, присвячена врегулюванню специфічних економічних відносин, - торговельне право. Торговельне право Німеччини спирається на норми інших галузей права й уникає чіткого визначення предмета регулювання, використовуючи абстрактні формулювання для регламентації багатьох важливих питань, чим суттєво відрізняється від галузей права України [2].

Торговий кодекс Німеччини (нім. Handelsgesetzbuch, скор. HGB) уводить такі основні поняття торгового права Німеччини: «комерсант» - фізична або юридична особа, яка внесена в торговий реєстр і яка займається одним із видів комерційної діяльності, зазначеної в Торговому кодексі, придбанням і продажем товарів, обробкою і переробкою виробів для інших осіб, страхуванням на оплатній основі, банківськими операціями, перевезеннями пасажирів і товарів; «офіційне найменування (фірма, фірмова назва) компанії» - назва, під якою комерсант веде свої справи; «торговий реєстр» - загальнодоступний публічний документ, до якого вносяться всі важливі відомості про комерційну діяльність компанії; «комерційний персонал» - співробітники компанії, наділені представницькими повнова-женнями від іiі імені, до яких належать прокурату, повноваження на ведення комерційних справ і торговельне представництво [5].

Торговий реєстр (нім. Handelsregister) у Німеччині - це державний реєстр, який містить детальну інформацію про всіх фізичних осіб-підприємців і юридичних осіб. Він складається 3 двох частин: перша містить список фізичних та юридичних осіб, які не мають статутного капіталу, друга - перелік всіх акціонерних компаній зі статутним капіталом. Доку- 
менти, на основі яких вносяться зміни до Реєстру (створення нового запису, його зміна чи вилучення), повинні бути нотаріально завірені. Торговий реєстр містить інформацію, зокрема про юридичну назву компанії; зареєстрований офіс; мету компанії; людей, що представляють компанію (керуючого директора, раду директорів, власників); організаційно-правову форму компанії; статутний капіталу, якщо такий є. Призначення Торгового реєстру - публікація, експертиза, контроль і зберігання інформації, яку він містить. Будь-хто може бути впевнений у точності відомостей, занесених до нього. Записи в Торговому реєстрі здійснюється суддею або спеціально уповноваженою особою. У більшості з 16 федеральних земель Реєстр зберігається в електронному вигляді [6].

Перед тим як відомості будуть занесені до реєстру, вони повинні бути розглянуті відповідним судом чи уповноваженою особою, які зобов'язані відхиляти заяви про реєстрацію у передбачених законом випадках. Заявник має право звернутися до апеляційного суду з оскарженням рішення місцевого суду про відмову в реєстрації. Невиконання службових обов'язків відповідною посадовою особою не призводить до відповідальності держави [7].

Будь-хто може запитати виписку з Торгового реєстру про конкретну компанію: так зване реєстраційне свідоцтво (Handelsregisterauszug, також HR-Auszug). Інформацію про зареєстровані компанії також можна отримати в Інтернеті, але для цього може знадобитися попередня реєстрація. Юридичні особи, як правило, зобов'язані публікувати свій річний звіт, відправивши його до Торгового реєстру. Це зобов'язання не залежить (з 2009 року) від розміру компанії.

Заявки на реєстрацію в Торговому реєстрі направляються до Федерального органу влади (Bundesanzeiger) та публікуються ним. У засобах масової інформації іноді також публікуються нові записи, хоча з 2009 року це не обов’язково. Крім того, всі зареєстровані компанії повинні представити свої річні звіти в Урядовий вісник (Bundesanzeiger) для публікації [6].

Торговий кодекс Німеччини містить положення про відкрите торговельне товариство (Offene Handelsgesellschaft, OHG), командитне товариство (Kommanditgesellschaft, KG) і негласне товариство (stille Gesellschaft). Торговий кодекс також регулює питання ухвалення рішень і звітності в господарських товариствах і містить додаткові норми щодо страхових компаній, кредитних організацій і товариств [7]. 
У регулюванні господарської діяльності Німеччини значну роль відіграє господарське адміністративне право. Господарське конституційне й господарське адміністративне право у ФРН перебувають у тісному взаємозв'язку й взаємодії. Аналіз німецької теорії правового регулювання господарської діяльності засвідчує, що господарське адміністративне право Німеччини є однією з правових галузей публічного права.

Господарське управління - це термін німецького господарського права. Для виконання завдань господарського управління держава й федеральні землі використовують не лише органи державного управління. Вони можуть довіряти певні сфери державним або земельним корпораціям і установам публічно-правового характеру, які підпадають під поняття непрямого державного або земельного управління.

Органи державного господарського управління використовують також для виконання своїх багатогранних завдань допомогу приватних адміністративних, відомчих і виконавчих помічників як інструмент для виконання завдань публічної влади. Вони не перебувають у прямих правовідносинах із третіми особами, як це характерно для уповноважених, а діють за дорученням і вказівкою органу влади [1].

Органи державного господарського права $є$ уособленням партнерства публічного й приватного секторів і принципу співробітництва. Крім того господарське державне управління різними способами користується послугами офіційно призначених експертів, експертних комісій та акредитованих осіб. Держава й федеральні землі все більше використовують можливість доручати здійснення завдання з господарського державного управління організованим на приватноправових принципах суб' єктам господарювання.

Завдання публічного управління на комунальному рівні виконуються насамперед відомствами та окремими громадськими службами (наприклад, відомством зі стимулювання економіки). Водночас так само, як і на державному й земельному рівнях, створюються муніципальні підприємства, які відносяться до юридично несамостійних державних підприємств на комунальному рівні. Крім того органи господарського самоврядування є носіями функцій господарського самоврядування. До них належать торгово-промислові, ремісничі, сільськогосподарські палати. 
Економічні палати (Kammer) існують на основі права земель. Вони зосереджуються на стимулюванні промислового сектора економіки; підвищенні кваліфікації; консультуванні органів державної влади, складанні експертних висновків тощо. Останнім часом палати розвиваються в напрямку їхнього становлення як сервісних центрів для підприємців і одночасно виконують численні завдання 3 охорони навколишнього середовища. Публічні організації ремесел поділяються на ремісничі гільдії, союзи гільдій, районні об'єднання ремісників, ремісничі палати. Гільдії та районні об'єднання виконують численні господарсько-адміністративні правові завдання, зокрема займаються питаннями професійного навчання й кваліфікаційних випробувань. Ці організації функціонують як наближені до місця діяльності ремісника центри з надання консалтингових послуг.

Сільськогосподарські палати є корпораціями публічного права, засно-ваними відповідно до права земель. Фінансування їх здійснюється за рахунок відрахувань сільгосппідприємств, державних асигнувань та інших джерел. Палати поділяються на місцеві й районні. Вони відповідають за роботу з фермерами, лісничими, садівниками й сільськогосподарськими робітниками. Їх завданнями $є$ визначення спільних інтересів сільського господарства, а також сприяння підвищенню економічності та екологічної сумісності сільськогосподарського виробництва й тваринництва [1].

Отже, адміністративно-торгове право ФРН є провідним інститутом, адміністративно-господарського права як підгалузі особливого адміністративного права, яке на основі реалізації норм торгового кодексу численними суб'єктами публічної адміністрації забезпечує баланс інтересів суб'єктів торговельної діяльності, споживачів, держави та суспільства в цілому.

\section{4. Висновки}

Стратегічною метою державного регулювання внутрішньої торгівлі $\epsilon$ формування та стабілізація споживчого ринку для задоволення соціальних потреб і недопущення соціальної напруженості у суспільстві. Співвідношення методів і механізмів державного регулювання розвитку внутрішньої торгівлі мають змінюватись у бік розширення та посилення результативності економічних методів впливу на їх розвиток на противагу заборонно-дозвільним або обмежувальним механізмам регулювання. 
Держава має бути ініціатором реформування у сфері торговельної діяльності, гарантом правового забезпечення рівних прав усіх суб'єктів права власності, законності та охорони прав споживачів. Державне регулювання правової держави з розвинутої ринковою економікою має обмежуватися моніторинговою політикою щодо антимонопольних принципів відносин суб'єктів ринку, сприяння розвитку конкуренції, дотримання прав і інтересів споживачів, інших правових норм регламентації підприємництва у сфері торгівлі; впливом на кадрове забезпечення торговельної діяльності у ринкових умовах. Шляхи розвитку адміністративно-правових засад роздрібної торгівлі полягають у формуванні конкурентного середовища; забезпеченні надійності та економічної конкурентоспроможності; недопущенні ліквідації соціально важливих торговельних підприємств; максимальній адаптації роздрібної торгівлі до потреб споживачів; поєднанні принципів вільного і регульованого формування роздрібної торговельної мережі; розвитку системи стандартизації та сертифікації; зменшенні переліку торговельної діяльності, яка підпадає під ліцензування; удосконаленні механізму протидії надходження у продаж неякісної продукції. Напрямками удосконалення адміністративно-правових засад оптової торгівлі $\epsilon$ створення умов для розвитку територіально розгалуженої мережі оптових підприємств; демонополізація каналів переміщення товарів; удосконалення стандартів у сфері оптової торгівлі.

3 огляду на вищесказане провідним шляхом удосконалення законодавства галузі внутрішньої торгівлі є доробка проекту Закону України «Про внутрішню торгівлю» з урахування таких пропозицій:

1) більш детально виписати права й обов'язки суб'єктів торговельної діяльності;

2) не створювати на місцях територіальні підрозділи спеціально уповноваженого органу виконавчої влади у сфері внутрішньої торгівлі, а його функції покласти на органи місцевого самоврядування та Державну податкову адміністрацію, позбавивши їх карних функцій;

3) чітко прописати обов'язки і права спеціально уповноваженого органу виконавчої влади у сфері внутрішньої торгівлі та делеговані повноваження органів місцевого самоврядування у цій сфері;

4) записати у перехідних положеннях, що ст. 24 діє до прийняття нового Кодексу про адміністративні проступки, а ст. 20 - до вступу в дію Адміністративно-процедурного кодексу України. 


\section{Список літератури:}

1. Посилення публічно-правового регулювання в ФРН - орієнтир для України: Національна бібліотека України імені В.I. Вернадського. URL: http://www.nbuv.gov.ua/portal/Soc_Gum/Dtr_pravo/2010_3/files/LA310_23.pdf (дата звернення: 20.10.2019).

2. Структура торговельного права Німеччини та ії вплив на особливості його застосування. Юридичний журнал. URL: http://justinian.com.ua/article. php?id=1153 (дата звернення: 20.10.2019).

Торговый кодекс Германии. Википедия. - свободная энциклопедия. URL: доступу : http://ru.wikipedia.org/wiki (дата звернення: 20.06.2019).

3. Хасанова В.В. Державне регулювання внутрішньої торгівлі в Україні (організаційно-правовий аспект) : автореф. ... канд. юридич. наук. Київ, 2009. 22 с.

4. Чехунов М.В. Ринкова трансформація внутрішньої торгівлі України : автореф. ... канд. економ. наук. Харків, 2001. 16 с.

5. Handelsgesetzbuch. Bundesministeriums der Jusitz. URL: http://www.gesetze-im-internet.de/hgb/index.html (дата звернення: 20.06.2019).

6. German Trade Register. Wikipedia. The Free Encyclopedia. URL: http://en.wikipedia.org/wiki/German_Trade Register (дата звернення 20.06.2019).

7. Handelsregister (Deutschland). Wikipedia. Die freie Enzyklopädie. URL: http://de.wikipedia.org/wiki/Handelsregister_(Deutschland) (дата звернення: 20.10.2019).

\section{References:}

1. Posilennya publichno-pravovogo regulyuvannya $\mathrm{v}$ FRN - oriyentir dlya Ukrayini: Nacionalna biblioteka Ukrayini imeni V.I. Vernadskogo. URL: http://www.nbuv.gov.ua/portal/Soc_Gum/Dtr_pravo/2010_3/files/LA310_23.pdf (accessed: 20.10.2019).

2. Struktura torgovelnogo prava Nimechchini ta yiyi vpliv na osoblivosti jogo zastosuvannya. Yuridichnij zhurnal. URL: http://justinian.com.ua/article. php?id=1153 (accessed: 20.10.2019).

Torgovyj kodeks Germanii. Vikipediya. - svobodnaya enciklopediya. URL: http://ru.wikipedia.org/wiki (accessed: 20.06.2019).

3. Hasanova V.V. Derzhavne regulyuvannya vnutrishnoyi torgivli v Ukrayini (organizacijno-pravovij aspekt) : avtoref. ....kand. yuridich. nauk. Kyiv, 2009. $22 \mathrm{~s}$.

4. Chehunov M.V. Rinkova transformaciya vnutrishnoyi torgivli Ukrayini : avtoref. ... kand. ekonom. nauk. Harkiv, 2001. 16 s.

5. Handelsgesetzbuch. Bundesministeriums der Jusitz. URL: http://www.gesetze-im-internet.de/hgb/index.html (accessed: 20.06.2019).

6. German Trade Register. Wikipedia. The Free Encyclopedia. URL: http://en.wikipedia.org/wiki/German Trade Register (accessed: 20.10.2019).

7. Handelsregister (Deutschland). Wikipedia. Die freie Enzyklopadie. URL: http://de.wikipedia.org/wiki/Handelsregister_(Deutschland) (accessed: 20.10.2019). 